\title{
Incorporation of Europium III Complex into Nanoparticles and Films Obtained by the Sol-Gel Methodology
}

\author{
Faley Jean de Sousa, Gilberto Pansani Altino de Lima, Lílian Rodrigues Ávila, \\ Katia Jorge Ciuffi, Paulo Sergio Calefi, Eduardo José Nassar*. \\ Universidade de Franca, Av. Dr. Armando Salles Oliveira, \\ 201 Pq. Universitário, 14404-600 Franca - SP, Brazil
}

Received: September 23, 2009; Revised: November 25, 2009

\begin{abstract}
The sol-gel process is very effective for the preparation of new materials with potential applications in optics, sensors, catalyst supports, coatings, and specialty inorganic polymers that can be used as hosts for the accommodation of organic molecules. The low temperature employed in the process is the main advantage of this methodology. In this work, the europium (III) complex with 1,10-phenantroline was prepared, and this luminescent complex was incorporated into silica nanoparticles and films by the sol-gel process. The nanoparticles were obtained by the modified Stöber methodology. The films were obtained by the dip-coating technique, at different deposition rates and numbers of layers. The nanoparticles and films were characterized by photoluminescence, thermal analysis, and Raman and infrared spectroscopies. Characterization revealed that the europium (III) complex was not affected upon incorporation into the nanoparticles and films, opening a new field for the application of these materials.
\end{abstract}

Keywords: photoluminescence, europium (III), nanoparticles, films, dip-coating

\section{Introduction}

The sol-gel process has been extensively studied over the last years because it enables the easy preparation of new materials that can be applied in several areas ${ }^{1-3}$. Multifunctional materials can be obtained by the sol-gel methodology by using low temperatures and organic (alkoxide) and inorganic (salt) precursors. The sol-gel process is based on hydrolysis and condensation reactions ${ }^{4-6}$. Properties such as the viscosity and gelation time are essential for the formation of the hybrid matrices (organic-inorganic) and have demonstrated the versatility of this methodology for the preparation of monoliths, films, fibers, powders, and nanoparticles ${ }^{3,7-17}$.

The current interest in the incorporation of luminescent species into host matrices is due to their application in solid state laser, chemical sensors, waveguide, and others. The sol-gel process can be employed in the preparation of luminescent glasses due to its ability to furnish doped structures. Rare earth ions are used as luminescence elements when incorporated in several matrix. The Eu (III) ion, in particular, allows the synthesis of several materials to be followed because its emission spectra, which depend on the surroundings of the ion ${ }^{19-26}$.

Thin films can be obtained by the sol-gel methodology using the $\operatorname{spin}^{27}$ and dip-coating ${ }^{28-31}$ technique, which enables adjustment of the microstructure through composition of the sol and the relative ratio between condensation and evaporation. The interest in thin films has increased because of their various applications, mainly in waveguide for integrated optics ${ }^{28,32,33}$ and other ${ }^{34,35}$

The preparation of thin films containing a rare earth complex by the sol-gel process for use as luminescent materials is advantageous due to the possibility of doping control ${ }^{36}$. Several studies using this methodology have been carried out, and they have provided information about the morphology and thermal stability of the films through the luminescent properties of the compounds incorporated into the films ${ }^{29-31,37}$.
In this work, the study of the luminescent properties of the europium (III) complex with 1,10-phenantroline incorporated into thin films and nanoparticles of silica obtained by the hydrolytic sol-gel process were evaluated for their potential applications as luminescent materials. The silica films were prepared by the dip-coating technique with different deposition rates and numbers of layers. The silica nanoparticles were obtained by the modified Stöber methodology. The materials obtained were characterized by Thermal Analysis (TA), Raman and Infrared spectroscopies (FTIR), Transmission Electronic Microscopy (TEM), and Photoluminescence (PL).

\section{Experimental}

\subsection{Preparation of the complex in solution}

Europium (III) chloride $\left(\mathrm{EuCl}_{3}\right)$ was prepared by dissolving europium (III) oxide (Aldrich), calcined at $900{ }^{\circ} \mathrm{C}$ for 2 hours in $\mathrm{HCl} 6$ mol.L ${ }^{-1}$ (Merck). The ethanolic $\mathrm{EuCl}_{3}$ solution $\left(1.0 \times 10^{-1} \mathrm{~mol} . \mathrm{L}^{-1}\right)$ was obtained by addition of ethanol.

The europium (III) complex with 1,10-phenantroline was prepared under stirring by firstly adding $200 \mathrm{mg}$ 1,10-phenantroline to $10.0 \mathrm{~mL}$ solvent (ethanol). Then, $2.0 \mathrm{~mL}$ of the europium (III) chloride ethanolic solution was added to the former solution and, after half an hour, $18.0 \mathrm{~mL}$ ethilic ether was poured into the resulting mixture and the complex precipitated. The solid power complex was filtered, washed and dried at $50{ }^{\circ} \mathrm{C}$ for 4 hours ${ }^{38}$. The thermal analysis confirmed the europium (III) complex was formed.

\subsection{Sol preparation}

The sol was prepared using silicon alkoxide tetraethylorthosilicate (TEOS, Aldrich) and ethanol as solvent. Then, $1 \%$ of the Eu (III)-phen complex $1.0 \times 10^{-1}$.mol. $\mathrm{L}^{-1}$ (molar ratio in relation to silicon) was 
added to the sol under stirring. An ammonium ethanolic solution was used as catalyst. After $30 \mathrm{~min}$, the films were deposited on a glass substrate. The ammonium ethanolic solution was prepared by burble ammonium vapour in the ethanol.

\subsection{Film deposition}

The films were obtained by using the dip-coating technique. The sol prepared was used to deposition films. The deposition rates were $10,50,100,200$, and $300 \mathrm{~mm} / \mathrm{min}$; the numbers of layers were 1,2 , and 3. The films were dried at room temperature $\left(\sim 25^{\circ} \mathrm{C}\right)$.

\subsection{Nanoparticles}

After films deposition, the solvent(ethanol) was evaporated and the powder was obtained. The solid was washed with ethanol and dried at $65^{\circ} \mathrm{C}$ for one day.

\subsection{Sample characterization}

\subsubsection{Themal Analysis (TA)}

Thermal analysis was carried out in a thermal analyzer (TA Instruments - SDT Q600 - Simultaneous DTA-TG) under nitrogen atmosphere, at a heating rate of $20^{\circ} \mathrm{C} / \mathrm{min}$, from 25 to $900{ }^{\circ} \mathrm{C}$.

\subsubsection{Infrared (FTIR)}

The infrared absorption spectra were obtained with a Mattson 7000 spectrophotometer with Fourier transform, using the KBr pellet technique.

\subsubsection{Transmission Electron Microscopy (TEM)}

The morphology of the system was investigated using transmission electron microscopy (Philips ${ }^{\circledR}$ CM 200 TEM, operating voltage $200 \mathrm{kV}$ ) to examine a drop of powder suspension deposited on a copper grid.

\subsection{Raman}

The Raman spectra were obtained on a Raman System Ocean Optics spectrophotometer with a laser diode $785 \mathrm{~nm}$ and detector CCD of 2048 elements.

\subsection{Photoluminescence (PL)}

Photoluminescence data were obtained under continuous Xe lamp (450W) excitation in a spectrofluometer SPEX - Fluorolog II, at room temperature. The emission was collected at $90{ }^{\circ} \mathrm{C}$ from the excitation beam. The slits were placed at 2.0 and $0.5 \mathrm{~mm}$ for excitation and emission, respectively, giving a band width of 7.0 and $1.0 \mathrm{~nm}$. Oriel 58916 (exc.) window until $550 \mathrm{~nm}$ and Corning 97612 (em.) window after $500 \mathrm{~nm}$, the filters were employed to remove the harmonic of the wavelength. All the spectra were corrected, with the software apparatus, for the lamp intensity and photomultiplier sensitivity at the monitored wavelengths. Decay curves were measured with a SPEX 1934 phosphorimeter, Xe lamp (5 J/pulse).

\section{Results and Discussion}

\subsection{Europium III complex}

\subsubsection{Thermal Analysis (TA)}

The termogravimetric curve (TG) and its derivative (DTG) revealed three weight losses for the synthesized $\mathrm{Eu}(\mathrm{III})$-phen complex. The first loss occurred from 67 to $154{ }^{\circ} \mathrm{C}$ and was ascribed to water molecules present in the complex. The second mass loss event took place between 255 and $531{ }^{\circ} \mathrm{C}$, and it is due to the decomposition of organic compounds (1,10-phenantroline). The last loss, which occurred above $800{ }^{\circ} \mathrm{C}$, refers to europium III oxide formation. Calculations led to the following molecular formula for the complex: $\left[\mathrm{Eu}(\text { phen })_{3}\left(\mathrm{H}_{2} \mathrm{O}\right)_{6}\right] \mathrm{Cl}_{3}$.

\subsection{Infrared (FTIR) and raman spectroscopies}

Formation of the $\left[\mathrm{Eu}(\text { phen })_{3}\left(\mathrm{H}_{2} \mathrm{O}\right)_{6}\right] \mathrm{Cl}_{3}$ complex was investigated by FTIR and Raman spectral analysis. The FTIR spectrum of 1,10-phenantroline displays bands corresponding to the vibration modes C-H $\left(3058 \mathrm{~cm}^{-1}\right), \mathrm{C}=\mathrm{N}\left(1648 \mathrm{~cm}^{-1}\right)$, and C-N $\left(1332 \mathrm{~cm}^{-1}\right)$. In the spectrum of the $\left[\mathrm{Eu}(\mathrm{phen})_{3}\left(\mathrm{H}_{2} \mathrm{O}\right)_{6}\right] \mathrm{Cl}_{3}$ complex, the vibration mode corresponding to $\mathrm{C}=\mathrm{N}$ shifted to $1621 \mathrm{~cm}^{-1}$, which indicates that the complex was indeed formed.

The Raman spectrum of 1,10-phenantroline display a band at $1594 \mathrm{~cm}^{-1}$, corresponding to the vibration modes C-C $\mathrm{C}_{\text {arom }}$ of this ligand. As for the $\left[\mathrm{Eu}(\text { phen })_{3}\left(\mathrm{H}_{2} \mathrm{O}\right)_{6}\right]_{\mathrm{Cl}_{3}}$ complex, this band was displaced to lower wavenumber $\left(1586 \mathrm{~cm}^{-1}\right)$, which once more gives evidence of the formation of the complex.

\subsection{Photoluminescence (PL)}

Both ligand-to-metal (LMCT) and metal-to-ligand (MLCT) transitions are allowed by Laporte's selection rule. Their energy is usually very large, so that they appear in the UV above $250 \mathrm{~nm}$, except for the ions which may be relatively easy to reduce to their +2 state (Sm (III), Eu (III), Tm (III), Yb (III)) or oxidize to their +4 state (Ce (III), Pr (III), Tb (III)). In these cases, the broad charge transfer transitions may occur at energies as low as $330 \mathrm{~nm}$. For the other ions, any assignment of LMCT transition below $250 \mathrm{~nm}$ must be considered dubious ${ }^{39}$. This excitation spectrum is typical of complexes described in the literature as having the maximum intensity appearing at $370 \mathrm{~nm}^{40,41}$.

Figure 1 shows the excitation spectrum of the $\left[\mathrm{Eu}(\mathrm{phen})_{3}\left(\mathrm{H}_{2} \mathrm{O}\right)_{6}\right] \mathrm{Cl}_{3}$ complex monitored at $615 \mathrm{~nm}$, which corresponds to the ${ }^{5} \mathrm{D}_{0} \rightarrow{ }^{7} \mathrm{~F}_{2}$ transition.

The excitation spectrum consists of a maximum peak at $356 \mathrm{~nm}$. The excitation bands are due to the absorption of the ligands and $\mathrm{f}-\mathrm{f}$ electron transitions of Eu (III). The absorption band at $356 \mathrm{~nm}$ is ascribed to the $\pi \rightarrow \pi^{*}$ band of the phen ligand. The wide band belongs to the ligand-metal charge transfer band (LMCT).

Figure 2 depicts the emission spectra of the $\left[\mathrm{Eu}(\text { phen })_{3}\left(\mathrm{H}_{2} \mathrm{O}\right)_{6}\right] \mathrm{Cl}_{3}$ complex monitored at 356, 394, and $465 \mathrm{~nm}$.

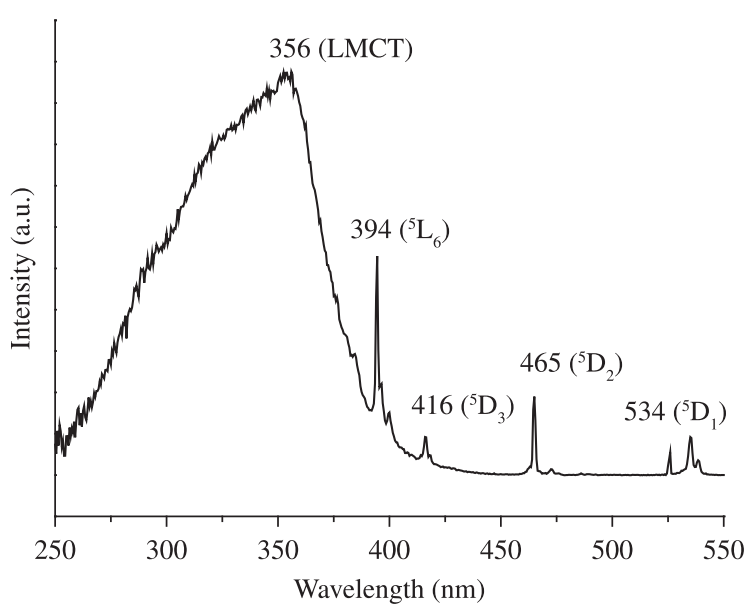

Figure 1. Excitation spectrum of the $\left[\mathrm{Eu}(\text { phen })_{3}\left(\mathrm{H}_{2} \mathrm{O}\right)_{6}\right] \mathrm{Cl}_{3}$ complex, $\lambda_{\mathrm{em}}=615 \mathrm{~nm}$. 
The energy levels of trivalent rare earth ions arising from the $4 \mathrm{f}^{\mathrm{n}}$ configuration, $4 \mathrm{f}^{\mathrm{n}}$ electrons are well shielded from the surroundings. Emission transitions yield, therefore, sharp lines in the spectrum ${ }^{42}$. The emission spectrum of the $\left[\mathrm{Eu}(\text { phen })_{3}\left(\mathrm{H}_{2} \mathrm{O}\right)_{6}\right]_{C} \mathrm{Cl}_{3}$ complex displays bands at $579.9 \mathrm{~nm}\left({ }^{5} \mathrm{D}_{0} \rightarrow{ }^{7} \mathrm{~F}_{0}\right) ; 591.6$ and $595.2 \mathrm{~nm}\left({ }^{5} \mathrm{D}_{0} \rightarrow{ }^{7} \mathrm{~F}_{1}\right) ; 612.8$ and $618.2 \mathrm{~nm}\left({ }^{5} \mathrm{D}_{0} \rightarrow{ }^{7} \mathrm{~F}_{2}\right) ; 649.8,652.2$ and $654.5 \mathrm{~nm}\left({ }^{5} \mathrm{D}_{0} \rightarrow{ }^{7} \mathrm{~F}_{3}\right)$; $690.7,695.4,699.5$ and $704.3 \mathrm{~nm}\left({ }^{5} \mathrm{D}_{0} \rightarrow{ }^{7} \mathrm{~F}_{4}\right)$. The large magnitude of the spin-orbit coupling in lanthanides causes the individual $\mathrm{J}$ levels of the various electronic terms to be well separated from each other, except for the gound ${ }^{7} \mathrm{~F}_{0}$ and emissive ${ }^{5} \mathrm{D}_{0}$ states of $\mathrm{Eu}$ (III), which are non-degenerated. The highly forbidden ${ }^{5} \mathrm{D}_{0} \rightarrow{ }^{7} \mathrm{~F}_{0}$ transition of Eu (III) is particularly important in that only a single transition is possible for a single $\mathrm{Eu}$ (III) ion environment ${ }^{43}$. The emission spectrum shows only one band in this region, indicating that the Eu (III) ion occupies one site in the complex. The ${ }^{5} \mathrm{D}_{0} \rightarrow{ }^{7} \mathrm{~F}_{0}$ transition is only observed when Eu (III) occupies a site without a symmetry center ${ }^{44}$. In the case of the present study, the emission spectrum agrees with the symmetry of complex, which corresponds to the $\mathrm{D}_{3}$ punctual group. The maximum wavelength for the transition ${ }^{5} \mathrm{D}_{0} \rightarrow{ }^{7} \mathrm{~F}_{\mathrm{J}}(\mathrm{J}=0,1,2,3$ and 4) did not

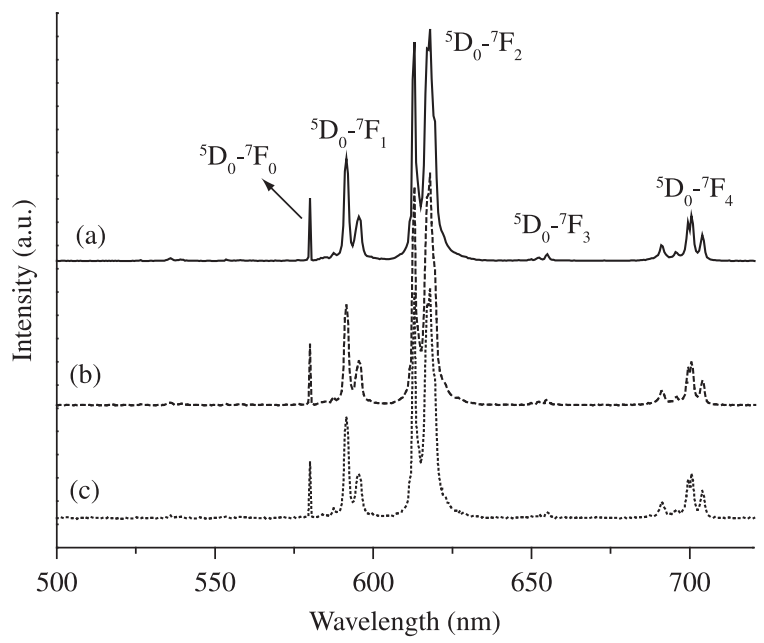

Figure 2. Emission spectra of the $\left[\mathrm{Eu}(\text { phen })_{3}\left(\mathrm{H}_{2} \mathrm{O}\right)_{6}\right] \mathrm{Cl}_{3}$ complex excited at different wavelengths, a) $356 \mathrm{~nm}$, b) $394.5 \mathrm{~nm}$, and c) $465 \mathrm{~nm}$.

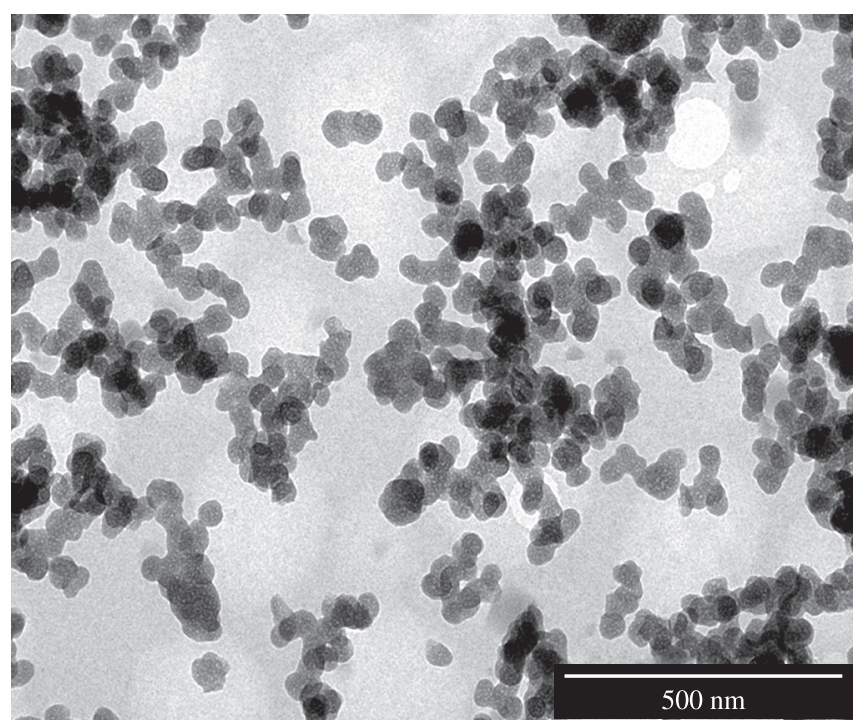

Figure 3. Transmission Electron Microscopy (TEM) of the silica matrix doped with the $\left[\mathrm{Eu}(\mathrm{phen})_{3}\left(\mathrm{H}_{2} \mathrm{O}\right)_{6}\right] \mathrm{Cl}_{3}$ complex. change when the samples were excited at different wavelengths, giving further evidence that there is one Eu (III) ion site.

\section{4. [ $\left.\mathrm{Eu}(\text { phen })_{3}\left(\mathrm{H}_{2} \mathrm{O}\right)_{6}\right] \mathrm{Cl}_{3}$ complex incorporated into silica nanoparticles}

\subsubsection{Themal Analysis (TA)}

The thermogravimetric curve and its derivative revealed two distinct weight loss stages for all the samples. The first loss occurred at $150{ }^{\circ} \mathrm{C}$ and corresponded to a loss of $8.29 \%$, which is ascribed to water and solvent molecules adsorbed on the matrix. The second stage, which took place between 150 and $650{ }^{\circ} \mathrm{C}$ and corresponded to a mass loss of $3.80 \%$, is due to the decomposition of the organic groups present in the $\left[\mathrm{Eu}(\text { phen })_{3}\left(\mathrm{H}_{2} \mathrm{O}\right)_{6}\right] \mathrm{Cl}_{3}$ complex. The $87.01 \%$ weight loss at $900{ }^{\circ} \mathrm{C}$ is ascribed mainly to the silica $\left(\mathrm{SiO}_{2}\right)$ and a little fraction of europium (III) oxide $\left(\mathrm{Eu}_{2} \mathrm{O}_{3}\right)$.

\subsection{Transmission Electron Microscopy (TEM)}

TEM can provide structural information about materials, such as particle shape, size, and crystallinity. Figure 3 presents TEM images of the europium complex in the silica matrix $\mathrm{SiO}_{2}:\left[\mathrm{Eu}(\mathrm{phen})_{3}\left(\mathrm{H}_{2} \mathrm{O}\right)_{6}\right] \mathrm{Cl}_{3}$.

The TEM image revealed the formation of nanoparticles with an average size of $30 \mathrm{~nm}$, with an initial process of particle sinterization. The form of the particles is not defined, which is probably due to incomplete hydrolysis and condensation of the precursor TEOS. The material is not formed by dense particles.

\subsection{Photoluminescence (PL)}

Figure 4 shows the excitation and emission spectra of the silica nanoparticles doped with the $\left[\mathrm{Eu}(\mathrm{phen})_{3}\left(\mathrm{H}_{2} \mathrm{O}\right)_{6}\right] \mathrm{Cl}_{3}$ complex.

The excitation spectrum shows a large band centered at $294 \mathrm{~nm}$, which is a typical ligand-metal charge transfer band (LMCT). However, when compared with the spectrum of the $\left[\mathrm{Eu}(\text { phen })_{3}\left(\mathrm{H}_{2} \mathrm{O}\right)_{6}\right]_{\mathrm{Cl}_{3}}$ complex, this band shifts from 356 to $294 \mathrm{~nm}$, which is attributed to interaction between the complex and the matrix.

The emission spectrum presents the characteristic line of the $\mathrm{Eu}$ (III) ion ${ }^{5} \mathrm{D}_{0} \rightarrow{ }^{7} \mathrm{~F}_{\mathrm{J}}(\mathrm{J}=0,1,2,3$, and 4) transition. The difference between the emission spectra of the $\left[\mathrm{Eu}(\text { phen })_{3}\left(\mathrm{H}_{2} \mathrm{O}\right)_{6}\right] \mathrm{Cl}_{3}$ complex and the same complex incorporated into the silica is related to band width. In this case, the electronic transition can be affected by changes in the surroundings of $\mathrm{Eu}$ (III), thereby promoting a non-homogeneous environment around the ion and leading to band widening.

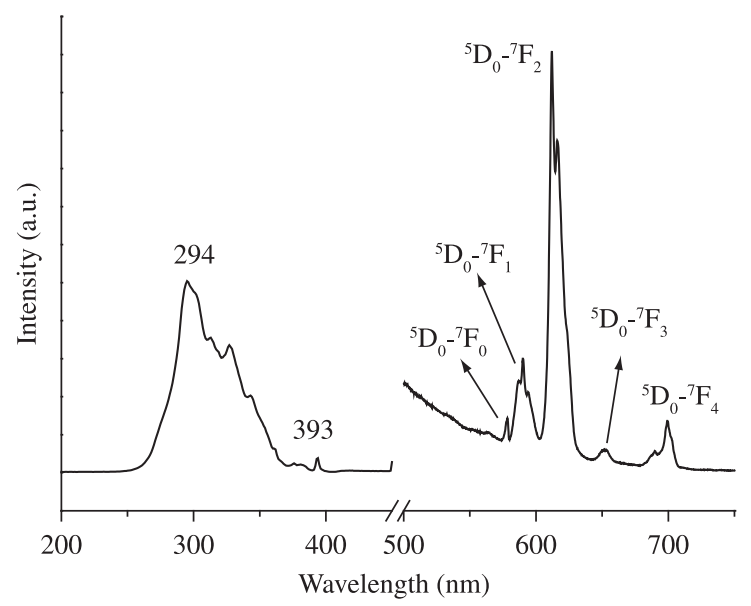

Figure 4. Excitation and emission spectra of the $\left[\mathrm{Eu}(\mathrm{phen})_{3}\left(\mathrm{H}_{2} \mathrm{O}\right) 6\right] \mathrm{C}_{13}$ complex incorporated into the silica matrix, $\lambda_{\text {em }}=610 \mathrm{~nm} ; \lambda_{\text {exc. }}=294 \mathrm{~nm}$. 


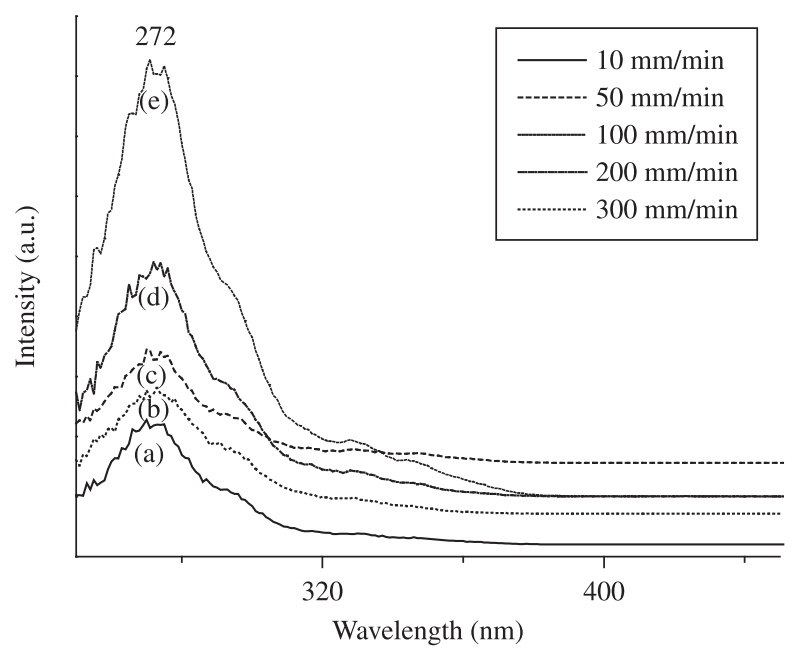

Figure 5. Excitation spectra of the $\left[\mathrm{Eu}(\text { phen })_{3}\left(\mathrm{H}_{2} \mathrm{O}\right)_{6}\right] \mathrm{Cl}_{3}$ complex incorporated into the silica films deposited at different rates, a) $10 \mathrm{~mm} / \mathrm{min}$, b) $50 \mathrm{~mm} / \mathrm{min}$, c) $100 \mathrm{~mm} / \mathrm{min}$, d) $200 \mathrm{~mm} / \mathrm{min}$, and e) $300 \mathrm{~mm} / \mathrm{min} . \lambda_{\mathrm{em}}=612 \mathrm{~nm}$.

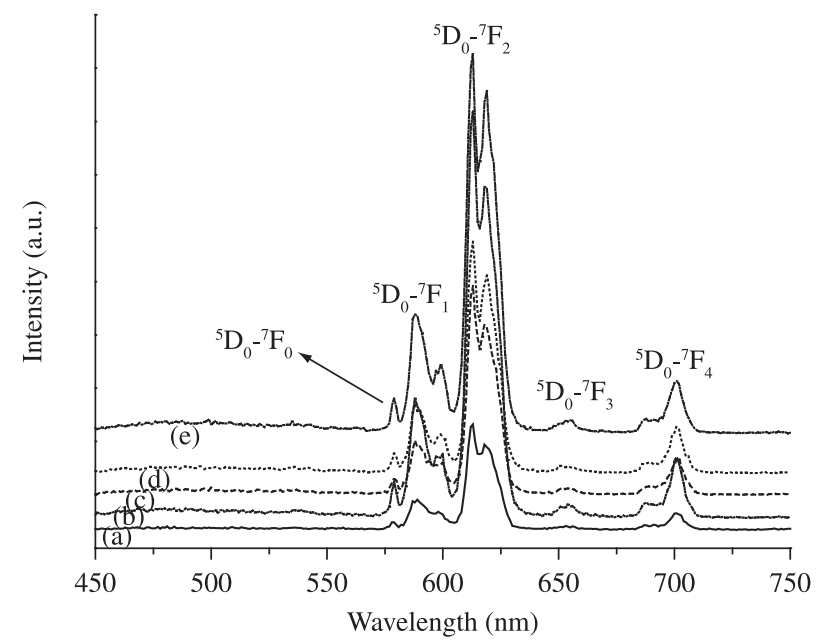

Figure 6. Emission spectra of the $\left[\mathrm{Eu}(\text { phen })_{3}\left(\mathrm{H}_{2} \mathrm{O}\right)_{6}\right] \mathrm{Cl}_{3}$ complex incorporated into the silica films deposited at different rates, a) $10 \mathrm{~mm} / \mathrm{min}$, b) $50 \mathrm{~mm} / \mathrm{min}$, c) $100 \mathrm{~mm} / \mathrm{min}$, d) $200 \mathrm{~mm} / \mathrm{min}$, and e) $300 \mathrm{~mm} / \mathrm{min} . \lambda_{\text {exc. }}=272 \mathrm{~nm}$.

\section{7. [ $\left.\mathrm{Eu}(\text { phen })_{3}\left(\mathrm{H}_{2} \mathrm{O}\right)_{6}\right] \mathrm{Cl}_{3}$ complex incorporated into silica thin films}

Figure 5 depicts the excitation spectra (monitored at $612 \mathrm{~nm}$ ) of the silica matrix doped with the $\left[\mathrm{Eu}(\text { phen })_{3}\left(\mathrm{H}_{2} \mathrm{O}\right)_{6}\right] \mathrm{Cl}_{3}$ complex and deposited on glass substrate at different deposition rates by the dip-coating technique.

The spectra display a large excitation band with maximum centered at $270 \mathrm{~nm}$, ascribed to the ligand-metal charge transfer band (LMCT). The shift of the maximum with relation to the complex incorporated into the non-deposited silica matrix $(294 \mathrm{~nm})$ can be due to interaction between the complex, the silica matrix and the glass substrate.

Figure 6 presents the emission spectra of the $\left[\mathrm{Eu}(\text { phen })_{3}\left(\mathrm{H}_{2} \mathrm{O}\right)_{6}\right] \mathrm{Cl}_{3}$ complex in the silica films deposited at different deposition rates and excited at $270 \mathrm{~nm}$ (LMCT).

The emission spectra of the $\left[\mathrm{Eu}(\mathrm{phen})_{3}\left(\mathrm{H}_{2} \mathrm{O}\right)_{6}\right] \mathrm{Cl}_{3}$ complex in the films displayed the bands corresponding to the electronic transitions from the excited state ${ }^{5} \mathrm{D}_{0}$ to the fundamental state ${ }^{7} \mathrm{~F}_{\mathrm{J}}$

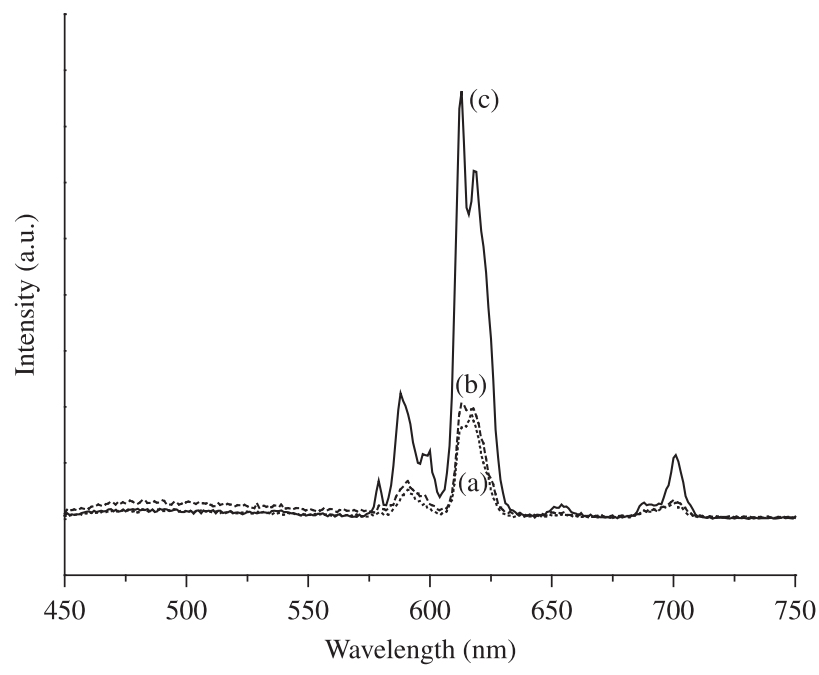

Figure 7. Emission spectra of the $\left[\mathrm{Eu}(\text { phen })_{3}\left(\mathrm{H}_{2} \mathrm{O}\right)_{6}\right] \mathrm{Cl}_{3}$ complex incorporated into the silica films with different numbers of layers, a) 1 layer, b) 2 layers, and c) 3 layers. $\lambda_{\text {exc. }}=272 \mathrm{~nm}$.

( $\mathrm{J}=0,1,2,3$, and 4$)$ of the Eu (III) ion. The spectra are similar to that observed for the complex in the silica matrix, indicating that $\left[\mathrm{Eu}(\text { phen })_{3}\left(\mathrm{H}_{2} \mathrm{O}\right)_{6}\right] \mathrm{Cl}_{3}$ is not affected upon incorporation into the film. The relative intensity increases with increasing deposition rate. The spectra of the complex in the film excited at the ${ }^{5} \mathrm{~L}_{6}$ $(393 \mathrm{~nm})$ level is very weak; the energy may correspond to ion - substrate transfer, and the blue emission in the $500 \mathrm{~nm}$ region can be due to the substrate.

The excitation spectra of the $\left[\mathrm{Eu}(\text { phen })_{3}\left(\mathrm{H}_{2} \mathrm{O}\right)_{6}\right] \mathrm{Cl}_{3}$ complex incorporated into the silica films deposited with different numbers of layers had similar behavior. The LMCT appeared at $272 \mathrm{~nm}$. Figure 7 shows the emission spectra for the complex in the films excited at $272 \mathrm{~nm}$ to films contend different number of layer.

There are not significative difference between emission spectra of the europium III complex incorporated in the nanoparticles and the films. This is an indicative that the compounds can be doped the nanosilica matrix in the particles form or thin films, do not change its characteristic luminescente properties.

\section{Conclusion}

Organic molecules that can absorb energy and transfer it to a metallic ion can be used to increase the quantum efficiency in a process known as the antenna effect. In this work we observed that the 1,10-phenatroline ligand can efficiently absorb and transfer energy to the $\mathrm{Eu}(\mathrm{III})$ ion when i) they form the $\left[\mathrm{Eu}(\mathrm{phen})_{3}\left(\mathrm{H}_{2} \mathrm{O}\right)_{6}\right] \mathrm{Cl}_{3}$ complex in solution, ii) the $\left[\mathrm{Eu}(\text { phen })_{3}\left(\mathrm{H}_{2} \mathrm{O}\right)_{6}\right] \mathrm{Cl}_{3}$ complex is incorporated into a silica matrix, iii) when the silica doped with the $\left[\mathrm{Eu}(\text { phen })_{3}\left(\mathrm{H}_{2} \mathrm{O}\right)_{6}\right] \mathrm{Cl}_{3}$ complex is deposited as a thin film. The solgel methodology enabled incorporation of the $\left[\mathrm{Eu}(\mathrm{phen})_{3}\left(\mathrm{H}_{2} \mathrm{O}\right)_{6}\right] \mathrm{Cl}_{3}$ complex into the matrix, which may be further employed as a light emission device.

The silica nanoparticles doped with the $\left[\mathrm{Eu}(\text { phen })_{3}\left(\mathrm{H}_{2} \mathrm{O}\right)_{6}\right] \mathrm{Cl}_{3}$ complex present good thermal stability $\left(\sim 350^{\circ} \mathrm{C}\right)$, suggesting that this material can be applied in systems requiring high temperatures.

The luminescence properties of the $\left[\mathrm{Eu}(\mathrm{phen})_{3}\left(\mathrm{H}_{2} \mathrm{O}\right)_{6}\right] \mathrm{Cl}_{3}$ complex are not affected upon its incorporation into the silica nanoparticles or nanoparticle deposition as thin film. This is important for its potential applications as luminescent materials, such as photonic materials, optical fibers, sensors, among others. 


\section{Acknowledgements}

The authors acknowledge FAPESP, CNPq, and CAPES (Brazilian research funding agencies) for financial support.

\section{References}

1. Hiratsuka RS, Santilli CV and Pulcinelli SH. O Processo Sol-Gel: uma visão físico-química. Química Nova. 1995; 18(2):171-180.

2. Ponton A, Griesmar P, Barboux-Doeuff S and Sanchez C. Rheological investigation of the sol-gel transition. Effect of hydrolysis variation in silicon oxide and titanium oxide based matrices. Journal of Materials Chemistry. 2001; 11:3125-3129

3. Sanchez C, Julián B, Belleville P and Popall M. Applications of irbid organic-inorganic nanocomposite. Journal of Materials Chemistry 2005; 15:3559-3592.

4. Nassar EJ, Nassor ECO, Ávila LR, Pereira PFS, Cestari A, Luz LM et al. Spherical hybrid silica particles modified by methacrylate groups. Journal of Sol-Gel Science and Technology. 2007; 43(1):21-26.

5. Nassar EJ, Ávila LR, Pereira PFS, Nassor ECO, Cestari A, Ciuffi KJ et al Fenilsilicato dopado com Eu III obtido pelo método sol-gel. Química Nova. 2007; 30(7):1567-1572.

6. Rocha LA, Ávila LR, Caetano BL, Molina EF, Sacco HC, Ciuffi KJ et al Europium incorporated into titanium oxide by sol-gel method. Materials Research. 2005; 8(3):361-364

7. Ararsu M, Sayilkan H, Sener S, Sayilkan F and Arpaç E. Synthesis, Characterization and Applications of Sol-Gel Derived Zirconium Oxide Adsorbent Powder of Phenol and p-Chlorophenol. Turkey Journal of Chemistry. 2003; 27:477-486.

8. Reisfield R. Prospects of sol-gel technology towards luminescent materials. Optical Materials. 2001; 16(1-2):1-7.

9. Nassar EJ, Ciuffi KJ, Gonçalves RR, Messaddeq Y and Ribeiro SJL. Filmes de titânio-slício preparados por "spin e dip-coating. Química Nova. 2003 26(5):674-677.

10. Niyama E, Alencar AC, Vila LD, Stucchi EB and Davolos MR. Filmes Delgados Luminescentes Obtidos a partir de Hidroxicarbonatos de Ítrio Ativados por Európio ou Térbio. Química Nova. 2004; 27(2):183-186.

11. Nassar EJ, Avila LR, Pereira PFS, Lima OJ, Rocha LA, Mello C et al. Óxido misto de ítrio-alumínio dopado com Eu (III). Química Nova. 2005; 28(2):238-243.

12. Airoldi C and Farias RF. Alcóxidos como Precursores na Síntese de Novos Materiais através do Processo Sol-Gel. Química Nova. 2004; 27(1):84-90.

13. Costa VC, Vasconcelos WL and Bray KL. Optical Characterization of Sol-Gel Glasses Derived from Eu ${ }^{3+}$ Complex-Forming Precursors. Química Nova. 1998; 21(3):374-377.

14. Serra OA, Calefi PS, Rosa ILV and Nassar EJ. Luminescence of a New $\mathrm{Tm}^{3+} \beta$-diketonate Compound. Journal of Alloys and Compounds. 1998; 275-277:838-840.

15. Lusar M and Sanchez C. Inorganic and Hybrid Nanofibrous Materials Templated with Organogelators. Chemistry of Materials. 2008; 20:782-820.

16. Avila LR, Nassor ECO, Pereira PFS, Cestari A, Ciuffi KJ, Calefi PS et al. Preparation and properties of europium-doped phosphosilicate glasses obtained by the sol-gel method. Journal of Non-Crystalline Solids. 2008; 354(42-44):4806-4810.

17. Avila LR, Faria EH, Ciuffi KJ, Nassar EJ, Calefi PS, Vicente MA et al. New synthesis strategies for effective functionalization of kaolinite and saponite with silylating agents. Journal of Colloids and Interfase Science. 2010; 341(1):186-193

18. Gvishi R. Fast sol-gel technology: from fabrication to applications. Journal of Sol-Gel Scence andi Technology. 2009; 50(2):241-253.

19. Pereira PFS, Caiut JMA, Ribeiro SJL, Messaddeq Y, Ciuffi KJ, Rocha LA et al. Microwave synthesis of YAG:Eu by sol-gel methodology. Journal of Luminescence. 2007; 126(2):378-382.

20. Nassar EJ, Pereira PFS, Nassor ECO, Ávila LR, Ciuffi KJ and Calefi PS. Nonhydrolytic sol-gel synthesis and characterization of YAG. Journal Materials Science. 2007; 42(7):2244-2249.

21. Ciuffi KJ, Nassar EJ, Rocha LA, Rocha ZN, Nakagaki S, Mata G et al. Preparation and characterization of new Ni-aluminosilicate calalysts and their performace in the epoxidation of (Z)-cyclooctene. Applied Catalysis A: General. 2007; 319:153-162.
22. Ciuffi KJ, Caetano BL, Rocha LA, Molina EF, Rocha ZN, Ricci GP et al Cobalt aluminu silicate complexes prepared by the non-hydrolytic sol-gel route and their catalytic activity in hydrocarbon oxidation. Applied Catalysis A: General. 2006; 311:122-134.

23. Papacidero AT, Rocha LA, Caetano BL, Molina EF, Sacco HC, Nassar EJ et al Preparation and charcterization of spherical sílica-porphyrin catalysts obtained by the sol-gel methodology. Colloids and Surfaces. 2006; 275(1-3):27-35.

24. Nassar EJ, Gonçalves RR, Ferrari M, Messaddeq Y and Ribeiro SJL. Titania Based Organic-Inorganic Hybrid Planar Waveguides. Journal of Alloys and Compounds. 2002; 34(1-2):221-225.

25. Zevin M and Reisfeld R. Preparation and properties of active waveguides based on zirconia glasses. Optical Materials. 1997; 8(1-2):37-41.

26. Binnemans K. Lanthanide-Based Luminescent Hybrid Materials. Chemical Reviews. 2009; 109(9):4283-4374.

27. Duverger C, Ferrari M, Mazzoleni C, Montagna M, Pucker G and Turrell $\mathrm{S}$. Optical spectroscopy of $\mathrm{Pr}^{3+}$ ions in sol-gel derived $\mathrm{GeO}_{2}-\mathrm{SiO}_{2}$ planar waveguides. Journal of Non-Crystaline Solids. 1999; 245(1-3):129-134.

28. Orignac S, Barbier D, Du XM, Almeida RM, McCarty O and Yatman E. Solgel silica/titania-on-silicon Er/Yb-doped waveguides for optical amplification at $1.5 \mu \mathrm{m}$. Optical Materials. 1999; 12(1):1-18.

29. Kudrawiec R, Misiewicz J, Bryja L, Molchan IS and Gaponenko NV. Photoluminescence investigation of porous anodic alumina with spin-on europium-containing titania sol-gel films. Journal of Alloys and Compounds. 2002; 341(1-2):211-213.

30. Faria EH, Marçal AL, Nassar EJ, Ciuffi KJ and Calefi PS. Sol-Gel TiO Thin Films Sensitized with the Mulberry Pigment Cyanidin. Materials Research. 2007; 10(4):413-417.

31. Rocha LA, Molina EF, Ciuffi KJ, Calefi PS and Nassar EJ. Eu (III) as a probe in titânia thin films: the effect of temperature. Materials Chemistry and Physics. 2007; 101(1):238-241.

32. Rocha LA, Ciuffi KJ, Sacco HC and Nassar EJ. Influence on deposition speed and stirring type in the obtantion of titânia films. Materials Chemistry and Physics. 2004; 85(2-3):245-250.

33. Zhang HJ, Fu LS, Wang SB, Meng QG, Yang KY and Ni JZ. Luminescence characteristics of europium and terbium complexes with 1,10-phenantroline in-situ synthesized in a silica matrix by a two-step sol-gel process. Materials Letters. 1999; 38(4):260-264.

34. Sanchez C, Boissière C, Grosso D, Laberty C and Design LN. Synthesis, and Properties of Inorganic and Hybrid Thin Films Having Periodically Organized Nanoporosity. Chemistry of Materials 2008; 20:682-737.

35. Bandeira LC, Campos BM, Faria EH, Ciuffi KJ, Calefi PS, Nassar EJ et al TG/DTG/DTA/DSC As a tool for studying deposition by the sol-gel process on materials obtained by rapid prototyping. Journal of Thermal Analysis and Calorimetry. 2009; 97(1):67-70.

36. Meng QG, Fu LS, Wang SB, Zhang HJ, Li HR, Chuai XH et al. Preparation and optical characterization of an organoeuropium-doped sol-gel transparent luminescence thin film. Thin Solid Films. 2001; 388(1-2):87-92

37. Souza LA, Messaddeq Y, Ribeiro SJL, Fredericci C, Lanciotti Jr. F and Pizani OS. Preparação de LiNbO3 e LiNbO3:Eu(III) pelo Método dos Precursores Poliméricos. Química Nova. 2002; 25(6B):1067-1071.

38. Hart FA and Laming FP. Lanthanide complexes-II: Complexes of 1:10-phenantroline with lanthanide acetates and nitrates. Journal of Inorganic and Nuclear Chemistry. 1965; 27(7):1065-1610.

39. Bunzli JCG, Comby S, Chauvin AS and Vandevyver CDB. New opportunities for lanthanide luminescence. Journal of Rare Earths. 2007; 25:257-274.

40. Lenaerts P, Ryckebosch E, Driesen K, Van Deun R, Nockemann P, GorllerWalrand $C$ et al. Study of the luminescence of tris(2-thenoyltrifluoroacetonato) lanthanide(III) complexes covalently linked to 1,10-phenanthrolinefunctionalized hybrid sol-gel glasses. Journal of Luminescence. 2005 114(1):77-84

41. Guo J, Fu L, Li H, Zheng Y, Meng Q, Wang S et al. Preparation and luminescence properties of ormosil hybrid materials doped with $\mathrm{Tb}$ (Tfacac) ${ }_{3}$ phen complex via a sol-gel process. Materials Letters. 2003; 57(24-25):3899-3903.

42. Blasse G and Grabmaier BD. Luminescent Materials. Heidelberg, Berlin: Spring-Verlag; 1994.

43. Horrocks WW and Albin Jr. M. Lanthanide ion luminescence in coordenation chemistry and biochemistry. Progress in Inorganc Chemistry. 1984; 31:1-104.

44. Carlos LD, Ferreira RAS, Bermudez V and Ribeiro SJL. Full-color phosphors from amine-functionalized crosslinked hybrids lacking metal activator ions. Advance Functional Materials. 2001; 11(2):111-115. 
